\title{
Biogenic and Risk Elements in Wines from the Slovak Market with the Estimation of Consumer Exposure
}

\author{
Magdalena Semla ${ }^{1}$ • Pavol Schwarcz ${ }^{2}$ - Ján Mezey ${ }^{3} \cdot$ Lukasz J. Binkowski $^{1}$. \\ Martyna Blaszczyk $^{1}$ - Grzegorz Formicki ${ }^{1} \cdot$ Agnieszka Greń $^{1} \cdot$ Robert Stawarz $^{1}$. \\ Peter Massanyi ${ }^{1,4}$
}

Received: 15 May 2017 / Accepted: 14 September 2017 /Published online: 7 October 2017

(C) The Author(s) 2017. This article is an open access publication

\begin{abstract}
Wine consumption delivers macroelements and microelements necessary for the proper metabolism. On the other hand, wine can be an important source of toxic metals. The aim of this study was to estimate the concentrations of $\mathrm{Ca}, \mathrm{Cd}$, $\mathrm{Cu}, \mathrm{Fe}, \mathrm{Hg}, \mathrm{Mg}, \mathrm{Ni}, \mathrm{Pb}$, and $\mathrm{Zn}$ in the Slovak and non-Slovak wines. The concentration of metals was evaluated with respect to the type, the alcohol content, and the age of Slovak wine. The general scheme of concentrations found was as follows $\mathrm{Ca}>\mathrm{Mg}>\mathrm{Fe}>\mathrm{Zn}>\mathrm{Pb}>\mathrm{Cd}>\mathrm{Ni}>\mathrm{Cu}>\mathrm{Hg}$. The type of wine and the alcohol content do not have a significant impact on metal concentrations. Also, the age of wine has no influence on the mean concentration of metals, except for $\mathrm{Zn}$. Metal concentrations in Slovak and non-Slovak wines indicate similar contents of metals, except for $\mathrm{Ni}$. The contribution to both dietary reference values (DRVs) and provisional tolerable weekly intake (PTWI) evaluations in the Slovak wine suggested low dietary exposure to $\mathrm{Ca}, \mathrm{Cu}, \mathrm{Fe}, \mathrm{Mg}, \mathrm{Ni}, \mathrm{Zn}$, $\mathrm{Cd}, \mathrm{Hg}$, and $\mathrm{Pb}$, respectively. However, we do not suggest that
\end{abstract}

the consumption of all Slovak wines is healthy. The maximum $\mathrm{Pb}$ concentrations in Slovak wines exceed the maximum permitted level proposed by the European Commission. This might be proved by the results of the margin of the exposure (MOE) value evaluation in the samples containing the maximum $\mathrm{Pb}$ concentrations, showing a high risk of CKD and SBP in high and extreme consumption groups.

Keywords Biogenic metals · DRV · MOE · PTWI · Slovakia $\cdot$ Wine

\section{Introduction}

Slovakia, thanks to its relatively warm climate, is a very dynamic and efficient wine producer and exporter. The total surface of Slovak vineyards is about 20,000 ha across the six main wine regions, mainly located in the southern part of

\author{
Robert Stawarz \\ robert.stawarz@gmail.com \\ Peter Massanyi \\ peter.massanyi@uniag.sk \\ Institute of Biology, Pedagogical University of Cracow, Podbrzezie \\ 3, 31-054 Krakow, Poland \\ 2 Department of EU Policies, Faculty of European Studies and \\ Regional Development, Slovak University of Agriculture, Trieda \\ Hlinku 2, 94901 Nitra, Slovak Republic \\ 3 Department of Fruit Growing, Viticulture and Enology, Faculty of \\ Horticulture and Landscape Engineering, Tulipánová 7, 949 \\ 76 Nitra, Slovak Republic \\ 4 Department of Animal Physiology, Slovak University of Agriculture, \\ Trieda Hlinku 2, 94901 Nitra, Slovak Republic
}


the country [1]. Growing wine industry contributes to the increase of wine consumption among the local population up to $18.3 \%$ of all the alcohol consumption which places the Slovak Republic on the 41st place of wine consumption in the world [2]. Wide Slovak wine consumption entails the need for careful control of wine quality and its impact on human health. Moreover, metals in wine may have a negative effect on the organoleptic properties of wine [3].

The popularity of wine is connected to its numerous bioactive molecules and natural elements which play an important role in health and prevention of diseases. Wine also constitutes the source of vitamins, macronutrients, and micronutrients, including metals [4]. Metals perform various functions in an organism, e.g., they participate in the synthesis and maintenance of the nucleic acid structure; they are parts of the basic compounds like proteins, lipids, hemoglobin, and enzymes essential for the functioning of the organism, and they play a fundamental role in the neuromuscular excitability and waterelectrolyte or acid-base balance [5-9]. Furthermore, metals contained in wine may be potentially toxic to humans. Exposure to heavy metals may lead to serious poisoning, circulatory system diseases, nervous system disease, and cancer [10]. Some metals in low concentrations are fundamental to the human organism, while at higher doses, they may pose a health risk $[7,8]$.

Metal concentrations in wine may have an impact on the quality of the wine. The bioavailability of metals may be an important factor in governing the fermentation performance by wine yeasts. Furthermore, metal concentrations are often responsible for imparting the salty character in wines [11]. Metal ions play an important role in oxidation and reduction reactions, which, in turn, affect the browning of wine, cloudiness, turbidity, and astringency [4].

Still, poorly understood is the mineral content of wine which affects its toxicity and human health. Daily consumption of wine in moderate quantities may be a source of mineral elements, required by the human organism [12]. On the other hand, high wine consumption may contribute to a large fraction of heavy metal intake. Additionally, the evaluation of the content of metals in the consumed wines is important due to their impact on the sensory attributes [11]. Therefore, the monitoring of metals in wine is advisable.

The aim of this study was to assess the concentration of calcium $(\mathrm{Ca})$, cadmium $(\mathrm{Cd})$, copper $(\mathrm{Cu})$, iron $(\mathrm{Fe})$, mercury $(\mathrm{Hg})$, magnesium $(\mathrm{Mg})$, nickel $(\mathrm{Ni})$, lead $(\mathrm{Pb})$, and zinc $(\mathrm{Zn})$ in the Slovak wine. We examined the concentration of metals depending on the type of wine (red, rose, and white), the alcohol content $(\geq 12$ and $<12 \%)$, and the age of wine $(\leq 2$ and $>2$ years). The correlations between metal concentrations were also checked. In addition, the concentrations of metals in the Slovak wines were compared with the metal content in the non-Slovak wines. Finally, for $\mathrm{Cd}, \mathrm{Pb}$, and $\mathrm{Hg}$ metals, the contribution to provisional tolerable weekly intake (PTWI) in the Slovak wine was also estimated. Furthermore, we assess the margin of the exposure (MOE) value for normal, high, and extreme Slovak wine consumption.

\section{Material and Methods}

Metal concentrations were determined in 56 Slovak wines available on the Slovak market and 21 from other countries (Australia, Bulgaria, the Czech Republic, Hungary, Italy, Moldova, Spain, Switzerland, the USA). The Slovak wines came from four regions and were divided into three groups according to the type of wine (white, red, rose), the alcohol content $(\geq 12$ and $<12 \%)$, and the age of wine $(\leq 2$ and $>2$ years).

All the metal analyses were determined in the laboratory of the Institute of Biology in the Pedagogical University of Cracow in Poland. All the samples (1 mL each) were mineralized in hot nitric acid $(65 \%$, Baker Analyzed, JT Baker, Deventer, the Netherlands) with the open mineralizer (Velp Scientifica DK-20, Usmate, Italy). The mineralized samples were used to prepare $10 \mathrm{~mL}$ solutions with ultrapure water (18.2 M $\Omega$ cm, Millipore Integral 3, Merck Millipore, Darmstadt, Germany). Concentrations of $\mathrm{Cd}, \mathrm{Ca}, \mathrm{Cu}, \mathrm{Fe}, \mathrm{Pb}$, $\mathrm{Mg}, \mathrm{Ni}$, and $\mathrm{Zn}$ were measured with flame atomic absorption spectrometer (PerkinElmer AAnalyst 200, PerkinElmer, Waltham, MA, USA).

$\mathrm{Hg}$ concentrations in wine samples $(150 \mu \mathrm{L}$ each) were determined with cold vapor atomic absorption spectrometer (MA-2, Nippon Instrument Corporation, Tokyo, Japan). Each sample was analyzed twice, and the mean value was calculated. The limits of the analytical methods were calculated for each metal according to the protocol described by Fleming et al. [13]. The validity of the whole procedure was checked against the certified reference material (ERM-CE195 CRMbovine-blood, Institute for Reference Materials and Measurements, Belgium; BCR-463-tuna fish, Joint Research Centre, Institute for Reference Materials and Measurement, Belgium; SRM1577b-bovine liver, National Institute of Standards \& Technology, USA, Table 1). For Mg and $\mathrm{Ni}$, the accuracy of the method was checked by ran repeated samples and spikes every ten samples studied. All the recoveries were found within the range of 90-110\%.

For $\mathrm{Cd}, \mathrm{Pb}$, and $\mathrm{Hg}$ metals, the contribution to PTWI in the Slovak wine was estimated per consumer $(70 \mathrm{~kg}$ of body weight) according to the formula:

PTWI contribution $\mu \mathrm{g} / \mathrm{kg} \mathrm{bw} /$ week $=\frac{M_{M e} \times 0.15}{m} \times 7$ days

$M_{M e}$ mean concentration of metals in milligrams per liter

$0.15150 \mathrm{~mL}$ wine/one glass/one person

$m \quad 70 \mathrm{~kg} /$ one person 
The estimated daily intake (EDI) provides an estimate of expected dietary exposure. EDI was calculated for the Slovak wine consumption for $\mathrm{Ca}, \mathrm{Cu}, \mathrm{Fe}, \mathrm{Mg}, \mathrm{Ni}$, and $\mathrm{Zn}$ metals [14]. The daily intake of metals depends on the metal concentration in wines $\left(M_{m e}\right)$ and the daily wine consumption $(150 \mathrm{~mL} / \mathrm{per}$ person/per day). In addition, the body weight $(70 \mathrm{~kg} /$ per person) of the human can influence the tolerance of contaminants.

EDI $\mathrm{mg} / \mathrm{kg}$ bw $/$ day $=\frac{M M e \times 0.15}{m}$

Panels on Dietetic Products, Nutrition, and Allergies developed a scientific opinion on dietary reference values (DRVs) for the European population. To estimate the DRVs, this opinion includes the average requirement (AR) and adequate intake (AI). For $\mathrm{Ca}, \mathrm{Fe}$, and $\mathrm{Zn}$, the DRVs in the Slovak wine were calculated on the basis of AR [15-17]. For $\mathrm{Cu}$ and $\mathrm{Mg}$, the DRVs were calculated on the base of AI $[18,19]$.

\section{Statistical Analysis}

Since the data met the demands of the parametric tests, we carried out the one-way ANOVA or $t$ test for particular categorical factors: type of wine, alcohol content, and age of the wine. We used Pearson correlation factors to evaluate the potential relationships between metals' concentrations and between concentration and age. The significance level was set at 0.050. All the calculations and analyses were done with Excel 2016 for Mac (Microsoft) and Statistica 12 (StatSoft).

\section{Results}

\section{Metal Concentrations in Slovak and Non-Slovak Wines}

The general scheme of ascending concentrations of metals in the studied Slovak wines was as follows $\mathrm{Ca}>\mathrm{Mg}>\mathrm{Fe}>\mathrm{Zn}>$ $\mathrm{Pb}>\mathrm{Cd}>\mathrm{Ni}>\mathrm{Cu}>\mathrm{Hg}$. In the non-Slovak wines, the general scheme of ascending concentrations was as follows: $\mathrm{Ca}>\mathrm{Mg}>\mathrm{Fe}>\mathrm{Zn}>\mathrm{Ni}>\mathrm{Cd}>\mathrm{Pb}>\mathrm{Cu}>\mathrm{Hg}$. Mean concentrations of $\mathrm{Ca}, \mathrm{Mg}, \mathrm{Fe}, \mathrm{Zn}, \mathrm{Cd}, \mathrm{Pb}, \mathrm{Cu}$, and $\mathrm{Hg}$ from the Slovak wine are comparable to the non-Slovak wine. Only the Ni concentration was significantly higher in the non-Slovak wines $(p<0.01)$. Furthermore, in three samples of the Slovak wine and one sample of the non-Slovak wine (from Hungary), the $\mathrm{Pb}$ concentrations were over $200 \mu \mathrm{g} / \mathrm{L}$ (Table 2).

\section{Influence of the Type of Wine, Alcohol Content, and Age of Wine on Metal Concentrations}

The type of wine did not have a significant impact on metal concentrations in the analyzed wine (Table 3 ). The trend showed that among all the metals tested, white wine was characterized by the highest concentrations of $\mathrm{Mg}, \mathrm{Pb}$, and $\mathrm{Zn}$. The highest concentrations of $\mathrm{Ca}$ and $\mathrm{Fe}$ were observed in the rose wine. Moreover, the highest concentrations of $\mathrm{Cd}$ and $\mathrm{Ni}$ metals were observed in the red wine. The $\mathrm{Cu}$ concentrations were similar in the white and red types of wine. Moreover, our results indicate $\mathrm{Hg}$ elements in the Slovak wine. The average $\mathrm{Hg}$ concentration was $0.001 \mathrm{mg} / \mathrm{L}$ in all the tested types of wine (Table 4).

Alcohol content in the Slovak wine did not have a significant impact on the metal concentration in the analyzed samples (Table 3). The general trend in the Slovak wine was that the wines containing more than $12 \%$ of alcohol characterized with higher $\mathrm{Ca}, \mathrm{Mg}, \mathrm{Ni}$, and $\mathrm{Pb}$ concentrations compared to other wines. The content of $\mathrm{Fe}, \mathrm{Cu}$, and $\mathrm{Hg}$ was the same in both analyzed contents of alcohol (Table 4).

Furthermore, metal concentrations in the analyzed wine do not depend on the age of the wine, except for $\mathrm{Zn}$. The wines more than 2 years of production have significantly higher concentrations of $\mathrm{Zn}$ than the 2-year or less-year-old wines (Table 3).

\section{Correlations of Metal Concentration}

Positive correlations between $\mathrm{Cu}-\mathrm{Fe}\left(r_{s} 0.29, p<0.05\right)$ and $\mathrm{Cu}-\mathrm{Zn}\left(r_{s} 0.43, p<0.05\right)$ concentrations in the Slovak wine were found. Moreover, the $\mathrm{Pb}$ concentration was positively correlated with the $\mathrm{Zn}$ content $(0.28)$. Also, a positive relationship between age of the wine and $\mathrm{Zn}$ concentration $\left(r_{s} 0.38\right.$, $p<0.05)$ was noted. The type of wine and alcohol content in the analyzed wine did not show correlations between the tested metals.

\section{Discussion}

In this study, all the tested metals were present in the Slovak wines. The type of wine and alcohol content did not have an impact on the metal content in the Slovak wine, contrary to the age of wine which has an impact on the $\mathrm{Zn}$ concentration. Furthermore, the Slovak wine is characterized by similar metal content as the non-Slovak wine, except for Ni. Lower Ni concentration in the Slovak wine was observed.

\section{Metal Concentrations}

Generally, the results showed that the Slovak wines contain macronutrients $(\mathrm{Ca}, \mathrm{Mg})$ and micronutrients $(\mathrm{Cu}, \mathrm{Fe}, \mathrm{Ni}, \mathrm{Zn})$ which play an important role in health and prevention of diseases $[4,7,8]$. The metal content may be influenced by many factors. Grape varieties, climate, soil, wine-making practices, $\mathrm{pH}$, and yeasts are some of the factors, which may impact the metal content in wines. The detected high concentrations of $\mathrm{Mg}$ and $\mathrm{Ca}$ metals can be caused by supplementing with 
Table 1 Parameters of the analytical procedure: recoveries for certified reference materials (CRMs, $n=10$ ) with relative standard deviation (RSD) of 10 replicates

\begin{tabular}{clclcc}
\hline Metals & Wavelength $\lambda(\mathrm{nm})$ & LoD $(\mathrm{mg} / \mathrm{L})$ & LoQ $(\mathrm{mg} / \mathrm{L})$ & Recovery $(\%)$ & RSD $(\%)$ \\
\hline $\mathrm{Ca}$ & 422.7 & 0.0642 & 0.514 & 108.2 & 6.6 \\
$\mathrm{Cd}$ & 228.8 & 0.0621 & 0.010 & 91.6 & 4.3 \\
$\mathrm{Cu}$ & 324.8 & 0.0876 & 0.035 & 99.6 & 2.7 \\
$\mathrm{Fe}$ & 248.3 & 0.005 & 0.415 & 101.6 & 6.2 \\
$\mathrm{Hg}$ & 253.7 & - & 0.27 & 97.1 & 2.6 \\
$\mathrm{Mg}$ & 285.2 & 0.00015 & 0.017 & - & - \\
$\mathrm{Ni}$ & 232.00 & 0.006 & 0.013 & - & - \\
$\mathrm{Pb}$ & 217.0 & 0.1039 & 0.107 & 93.7 & 6.2 \\
$\mathrm{Zn}$ & 213.9 & 0.0170 & 0.024 & 106.2 & 5.3 \\
\hline
\end{tabular}

For $\mathrm{Cd}$ and $\mathrm{Pb}$, ERMCE195 CRM were used; for Hg, BCR-463 CRM was used and for other elements, SRM1577b; no appropriate CRM for $\mathrm{Mg}$ and $\mathrm{Ni}$ were found

$L o D$ limits of detection (in solution), $L o Q$ limits of quantification established for wine samples

${ }^{\text {a }} \mathrm{LoQ}$ value for $\mathrm{Hg}$ expressed as a nanograms per liter growth media which stimulates the yeast growth [20]. Fertilizers and pesticides (mainly fungicides) applied during the growing season of vines may affect, in the tested wine, the presence of elements, like $\mathrm{Cd}, \mathrm{Cu}, \mathrm{Fe}, \mathrm{Pb}$, and $\mathrm{Ni}$. Moreover, the location of the vineyards in close proximity to road traffic and industrial areas or the wine production and storage may have an impact on the Slovak wine production [12]. Furthermore, the substance contained copper sulfate, used to spray the wines to prevent mildew, which may be the source of $\mathrm{Cu}$ in wine [21]. The presence of $\mathrm{Pb}$ metal in the Slovak wine may be caused by the existence of this metal in some glass bottles, which may lead to wine contamination. It can be observed especially in decorative, crystal bottles in which the concentration of lead is very high. The longer the wine is stored in these bottles, the higher the $\mathrm{Pb}$ concentration detected [22]. Moreover, the presence of $\mathrm{Hg}$ metal in the Slovak wine may be indicated with air, water, and soil pollution or industrial area [23]. Furthermore, we found that the type of wine and the alcohol content do not affect metal concentration. Also, the age of wine had no influence on the metal level, except for $\mathrm{Zn}$. Higher concentrations of $\mathrm{Zn}$ in the Slovak wines more than 2 years of production can be affected by the production process and wine aging [21]. Only a few moderately strong correlations between metal concentrations in the Slovak wine were found. Positive relationships between $\mathrm{Cu}$ $\mathrm{Fe}$ and $\mathrm{Cu}-\mathrm{Zn}$ elements may be associated with the production methods. $\mathrm{Cu}, \mathrm{Fe}$, and $\mathrm{Zn}$ metals are very important for the efficient alcoholic fermentation and alcohol production in yeast biomass. During fermentation, the concentrations of these metals are favorable for yeasts as they are required for prosthetic metallo-enzyme activation [24]. Moreover, a strong relationship was detected in $\mathrm{Zn}$ and $\mathrm{Pb}$ concentration which may be associated with the use of pesticides and fertilizers containing $\mathrm{Pb}$ and $\mathrm{Zn}$ compounds. The application of those chemical substances during the growing season of vines leads to the increase in the amounts of these metals in wine [12]. The relationship between the age of wine and $\mathrm{Zn}$ concentrations, found in this study, can be associated with longterm storage of wine in galvanized containers rich in $\mathrm{Zn}$ compounds [21].

Table 2 Concentrations of metals $(\mathrm{mg} / \mathrm{L})$ in Slovak $(n=56)$ and non-Slovak $(n=21)$ wine with statistical comparison $(t$ test $)$ between groups studied

\begin{tabular}{|c|c|c|c|c|c|c|c|c|c|c|}
\hline \multirow[t]{2}{*}{ Metals } & \multicolumn{4}{|c|}{ Slovak wine } & \multicolumn{4}{|c|}{ Non-Slovak wine } & \multirow[t]{2}{*}{$t$} & \multirow[t]{2}{*}{$p$ value } \\
\hline & Mean & $\mathrm{SD}$ & Minimum & Maximum & Mean & SD & Minimum & Maximum & & \\
\hline $\mathrm{Ca}$ & 2.64 & 1.46 & 0.00 & 9.71 & 2.17 & 1.07 & 0.44 & 3.79 & 1.36 & 0.18 \\
\hline $\mathrm{Cd}$ & 0.07 & 0.04 & 0.00 & 0.15 & 0.07 & 0.04 & 0.00 & 0.13 & -0.26 & 0.79 \\
\hline $\mathrm{Cu}$ & 0.03 & 0.02 & 0.00 & 0.08 & 0.03 & 0.02 & 0.00 & 0.08 & -0.48 & 0.63 \\
\hline $\mathrm{Fe}$ & 0.35 & 0.17 & 0.10 & 0.99 & 0.39 & 0.20 & 0.10 & 0.79 & -0.89 & 0.37 \\
\hline $\mathrm{Hg}$ & 0.001 & 0.001 & 0.00 & 0.01 & 0.00 & 0.00 & 0.00 & 0.00 & 0.79 & 0.43 \\
\hline $\mathrm{Mg}$ & 0.66 & 0.84 & 0.06 & 5.97 & 0.65 & 0.37 & 0.09 & 1.28 & 0.04 & 0.97 \\
\hline $\mathrm{Ni}$ & 0.04 & 0.05 & 0.00 & 0.23 & 0.09 & 0.11 & 0.00 & 0.51 & -2.73 & 0.01 \\
\hline $\mathrm{Pb}$ & 0.08 & 0.06 & 0.00 & 0.25 & 0.06 & 0.06 & 0.00 & 0.21 & 1.19 & 0.24 \\
\hline $\mathrm{Zn}$ & 0.19 & 0.20 & 0.01 & 1.44 & 0.21 & 0.16 & 0.02 & 0.62 & -0.38 & 0.70 \\
\hline
\end{tabular}


Table 3 Statistical differences in mean metal concentrations $(n=56)$ in respect of the type of wine (ANOVA), alcohol content, and age of wine $(t$ test $)$

\begin{tabular}{|c|c|c|c|c|c|c|}
\hline \multirow[t]{2}{*}{ Metals } & \multicolumn{2}{|c|}{ Type of wine (white, red, rose) } & \multicolumn{2}{|c|}{ Alcohol content $(\%)(\geq 12 ;<12)$} & \multicolumn{2}{|c|}{ Age of wine (years) $(\leq 2 ;>2$} \\
\hline & $F$ & $p$ & $t$ & $p$ & $t$ & $p$ \\
\hline $\mathrm{Ca}$ & 0.44 & 0.65 & -1.22 & 0.23 & 0.80 & 0.43 \\
\hline $\mathrm{Cd}$ & 2.05 & 0.14 & 0.87 & 0.39 & 0.64 & 0.53 \\
\hline $\mathrm{Cu}$ & 1.62 & 0.21 & -0.76 & 0.45 & -1.08 & 0.28 \\
\hline $\mathrm{Fe}$ & 1.36 & 0.27 & 0.10 & 0.92 & -0.81 & 0.42 \\
\hline $\mathrm{Hg}$ & 0.93 & 0.40 & -0.26 & 0.80 & 0.49 & 0.63 \\
\hline $\mathrm{Mg}$ & 0.54 & 0.59 & -1.48 & 0.14 & 1.22 & 0.23 \\
\hline $\mathrm{Ni}$ & 0.71 & 0.50 & -0.69 & 0.50 & 1.66 & 0.10 \\
\hline $\mathrm{Pb}$ & 0.62 & 0.54 & -0.75 & 0.46 & -0.21 & 0.84 \\
\hline $\mathrm{Zn}$ & 0.13 & 0.87 & 1.04 & 0.30 & -2.17 & 0.03 \\
\hline
\end{tabular}

We noted that metal concentrations in the Slovak and nonSlovak wines indicate similar contents of metals, except for the Ni element. High Ni concentration in the non-Slovak wine may suggest that Ni contamination can be derived from stainless steel storage tanks and from the pigments of bottles during the storage of wines [25]. On the other hand, when compared to the data gathered in literature, the $\mathrm{Ca}, \mathrm{Fe}, \mathrm{Mg}$, and $\mathrm{Zn}$ concentrations, generally, reach lower values in the Slovak wine as compared to the European ones (Table 5). This observation can be attributed to soil parameters which can significantly affect the composition of grapes and wine $[27,28]$. In addition, we noted that Cd concentration in the Slovak wines is higher than in the Czech, Cretan, and Spanish wines (Table 5). The Cd pollution may vary greatly with the geographic, demographic, and the social-economic profile of a region [29]. The highest Cd pollution in Slovakia may be associated with the metallurgical industry and agriculture [30]. In addition, due to the Slovakia's close vicinity of Poland, the main sources of cadmium industrial emissions in this area are in the Upper Silesian Industrial Region of Poland [31]. Generally, the concentrations of $\mathrm{Cu}, \mathrm{Ni}$, and $\mathrm{Pb}$ in the
Slovak wines fall within the range noted in the European wines. According to the regulation issued by the European Commission [32], the maximum permitted level for the $\mathrm{Pb}$ content in wines is $200 \mu \mathrm{g} / \mathrm{L}$ for wines produced from the 2001 to 2015 fruit harvest. The maximum level of $\mathrm{Pb}$ measured in the Slovak wines is $250 \mu \mathrm{g} / \mathrm{L}$ which is higher than the permitted level (Table 2). These wines are sold in the Slovak market which may constitute a health threat. Metal toxicity depends on the absorbed dose, the route of exposure, and the duration of exposure. Exposure to high levels of $\mathrm{Pb}$ can cause brain damage, paralysis, anemia, and gastrointestinal symptoms. Furthermore, the mechanism of $\mathrm{Pb}$ toxicity causes significant changes in various biological processes such as cell adhesion, intracellular and intercellular signaling, protein folding, apoptosis, enzyme regulation maturation, ionic transportation, and release of neurotransmitters [33].

Moreover, the $\mathrm{Hg}$ concentration in our study cannot be compared with European wines because literature does not show $\mathrm{Hg}$ in European wine. However, the $\mathrm{Hg}$ concentration found in the studied wine may be indicated with soil and air pollution [28].

Table 4 Metal concentration in Slovak wine (mean $\pm \mathrm{SD}, \mathrm{mg} / \mathrm{L}, n=56$ ) depending on the type of wine, alcohol content, and age of wine

\begin{tabular}{|c|c|c|c|c|c|c|c|}
\hline \multirow[t]{2}{*}{ Metal } & \multicolumn{3}{|l|}{ Type of wine } & \multicolumn{2}{|c|}{ Alcohol content $(\%)$} & \multicolumn{2}{|c|}{ Age of wine (years) } \\
\hline & White $(n=37)$ & $\operatorname{Red}(n=7)$ & Rose $(n=12)$ & $\geq 12(n=40)$ & $<12(n=16)$ & $\leq 2(n=42)$ & $>2(n=14)$ \\
\hline $\mathrm{Ca}$ & $2.72 \pm 1.58$ & $2.29 \pm 1.32$ & $2.82 \pm 0.99$ & $2.49 \pm 1.12$ & $3.02 \pm 2.07$ & $2.73 \pm 1.58$ & $2.37 \pm 1.00$ \\
\hline $\mathrm{Cd}$ & $0.06 \pm 0.04$ & $0.09 \pm 0.03$ & $0.07 \pm 0.04$ & $0.07 \pm 0.04$ & $0.06 \pm 0.04$ & $0.07 \pm 0.04$ & $0.06 \pm 0.05$ \\
\hline $\mathrm{Cu}$ & $0.03 \pm 0.02$ & $0.03 \pm 0.01$ & $0.02 \pm 0.02$ & $0.03 \pm 0.02$ & $0.03 \pm 0.03$ & $0.03 \pm 0.02$ & $0.03 \pm 0.02$ \\
\hline $\mathrm{Fe}$ & $0.32 \pm 0.15$ & $0.40 \pm 0.14$ & $0.41 \pm 0.29$ & $0.35 \pm 0.17$ & $0.35 \pm 0.16$ & $0.34 \pm 0.17$ & $0.38 \pm 0.15$ \\
\hline $\mathrm{Hg}$ & $0.001 \pm 0.001$ & $0.001 \pm 0.001$ & $0.001 \pm 0.001$ & $0.001 \pm 0.001$ & $0.001 \pm 0.001$ & $0.001 \pm 0.001$ & $0.001 \pm 0.001$ \\
\hline $\mathrm{Mg}$ & $0.74 \pm 0.98$ & $0.50 \pm 0.36$ & $0.49 \pm 0.58$ & $0.56 \pm 0.45$ & $0.92 \pm 1.40$ & $0.74 \pm 0.93$ & $0.42 \pm 0.41$ \\
\hline $\mathrm{Ni}$ & $0.04 \pm 0.05$ & $0.06 \pm 0.04$ & $0.03 \pm 0.05$ & $0.04 \pm 0.04$ & $0.05 \pm 0.06$ & $0.05 \pm 0.05$ & $0.02 \pm 0.03$ \\
\hline $\mathrm{Pb}$ & $0.09 \pm 0.06$ & $0.06 \pm 0.08$ & $0.08 \pm 0.05$ & $0.08 \pm 0.06$ & $0.09 \pm 0.06$ & $0.08 \pm 0.07$ & $0.08 \pm 0.06$ \\
\hline $\mathrm{Zn}$ & $0.20 \pm 0.24$ & $0.17 \pm 0.09$ & $0.18 \pm 0.07$ & $0.21 \pm 0.22$ & $0.15 \pm 0.11$ & $0.16 \pm 0.09$ & $0.29 \pm 0.35$ \\
\hline
\end{tabular}


Table 5 Concentration of metals $(\mathrm{mg} / \mathrm{L})$ in wine from four countries in Europe

\begin{tabular}{ccccc}
\hline Metals & Czech wine $^{\mathrm{a}}$ & Cretan wine $^{\mathrm{b}}$ & German wine $^{\mathrm{c}}$ & Spanish wine $^{\mathrm{d}}$ \\
\hline $\mathrm{Ca}$ & $40-100$ & - & $58-200$ & $12-241$ \\
$\mathrm{Cd}$ & $0.000055-0.0033$ & $0-0.006$ & - & $0.00-0.019$ \\
$\mathrm{Cu}$ & $0.012-6.827$ & $0.2-0.6$ & $0.02-0.71$ & $0.00-3.1$ \\
$\mathrm{Fe}$ & $0.9-5.2$ & $4.7-12$ & $0.4-4.2$ & $0.4-17.4$ \\
$\mathrm{Hg}$ & - & - & - & - \\
$\mathrm{Mg}$ & $7.8-138$ & - & $56-105$ & $50-236$ \\
$\mathrm{Ni}$ & $0.019-0.034$ & $0-2.3$ & - & $0.005-0.079$ \\
$\mathrm{~Pb}$ & $0.010-1.253$ & $0.018-0.42$ & - & $0.001-0.096$ \\
$\mathrm{Zn}$ & - & $0.3-31$ & $0.3-1.5$ & $0.00-4.63$ \\
\hline
\end{tabular}

${ }^{\mathrm{a}}$ [26]

${ }^{\mathrm{b}}$ [21]

c [24]

d [24]

\section{Consumer Risk Assessment}

EDI and DRVs were calculated for $\mathrm{Ca}, \mathrm{Cu}, \mathrm{Fe}, \mathrm{Mg}, \mathrm{Ni}$, and $\mathrm{Zn}$, because the metals occur in the body at high concentrations. The comparison of EDI with respect to tolerable daily intake (TDI) for $\mathrm{Ca}, \mathrm{Cu}, \mathrm{Fe}, \mathrm{Mg}$, and $\mathrm{Zn}$ indicated that daily intake of one glass of the Slovak wine, containing mean and maximum concentrations of these metals, provides less than $0.01 \%$ of TDI and does not pose a threat to human health
(Table 6). The maximum daily intake of $\mathrm{Ni}$ corresponds to $35 \%$ of the TDI (Table 6). The compounds of Ni are considered as carcinogens [36]. The estimation of the TDI of Ni has been recently reduced from 8 to $2.8 \mu \mathrm{g} /$ day [26]. The DRVs are the complete set of nutrient recommendations and reference values, such as population reference intakes, the average requirement, adequate intake level, and the lower threshold intake. The EFSA Panel on Dietetic Products, Nutrition, and Allergies [15-19] estimated DRVs for $\mathrm{Ca}, \mathrm{Cu}, \mathrm{Fe}, \mathrm{Mg}$, and
Table 6 Estimated daily intake (EDI) and contribution to the dietary reference values (DRVs) of metals in Slovak wine

\begin{tabular}{|c|c|c|c|}
\hline $\begin{array}{l}\text { Metals concentration } \\
(\mathrm{mg} / \mathrm{L})\end{array}$ & $\begin{array}{l}\text { EDI/RDI } \\
(\mathrm{mg} / \mathrm{kg} \text { bw/day })^{\mathrm{a}}\end{array}$ & TDI (mg/kg bw/day) ${ }^{\mathrm{b}}$ & $\begin{array}{l}\text { Contribution to } \\
\text { DRVs }(\%)^{\mathrm{c}}\end{array}$ \\
\hline \multicolumn{4}{|l|}{$\mathrm{Ca}$} \\
\hline Mean 2.64 & 0.006 & \multirow[t]{2}{*}{10,000} & 0.001 \\
\hline Max. 9.71 & 0.02 & & 0.003 \\
\hline \multicolumn{4}{|l|}{$\mathrm{Cu}$} \\
\hline Mean 0.03 & 0.0001 & \multirow[t]{2}{*}{10} & 0.01 \\
\hline Max. 0.08 & 0.0002 & & 0.013 \\
\hline \multicolumn{4}{|l|}{$\mathrm{Fe}$} \\
\hline Mean 0.35 & 0.001 & \multirow[t]{2}{*}{18} & 0.0003 \\
\hline Max. 0.99 & 0.002 & & 0.03 \\
\hline \multicolumn{4}{|l|}{$\mathrm{Mg}$} \\
\hline Mean 0.66 & 0.001 & \multirow[t]{2}{*}{350} & 0.0003 \\
\hline Max. 5.97 & 0.013 & & 0.004 \\
\hline \multicolumn{4}{|l|}{$\mathrm{Ni}$} \\
\hline Mean 0.4 & 0.0001 & \multirow[t]{2}{*}{0.0028} & \multirow[t]{2}{*}{-} \\
\hline Max. 0.23 & 0.001 & & \\
\hline \multicolumn{4}{|l|}{$\mathrm{Zn}$} \\
\hline Mean 0.19 & 0.0004 & \multirow[t]{2}{*}{40} & 0.003 \\
\hline Max. 1.44 & 0.0031 & & 0.024 \\
\hline
\end{tabular}

${ }^{\text {a }}$ EDI values calculated on the basis of $150 \mathrm{~mL}$ consumption (one glass) per person (70 kg) per day

${ }^{\mathrm{b}}$ Tolerable daily intake (TDI) for $\mathrm{Cu}, \mathrm{Ni}$, and $\mathrm{Zn}$ [34]; recommended daily intake (RDI) for $\mathrm{Ca}, \mathrm{Fe}$, and $\mathrm{Mg}$ [35]

${ }^{\mathrm{c}} \mathrm{For} \mathrm{Ca}, \mathrm{Fe}$, and $\mathrm{Zn}$ calculated based on average requirement (AR) [15-17]; for $\mathrm{Cu}$ and $\mathrm{Mg}$ calculated based on adequate intake (AI) $[18,19]$ 
Table 7 The mean concentration of $\mathrm{Pb}, \mathrm{Cd}$, and $\mathrm{Hg}$ in Slovak wine and contribution to the provisional tolerable weekly intake value (PTWI $\mu \mathrm{g} / \mathrm{kg}$ bw/week) calculated for $70 \mathrm{~kg}$ person

\begin{tabular}{lllll}
\hline Metals & $\begin{array}{l}\text { mg Cd or Hg or } \\
\text { Pb per 150 mL wine }\end{array}$ & $\begin{array}{l}\mu \text { Cd or Hg or Pb per } \\
\text { one person per week }\end{array}$ & $\begin{array}{l}\text { Contribution to } \\
\text { PTWI }(\%)\end{array}$ & $\begin{array}{l}\text { PTWI } \\
(\mu \mathrm{g} / \mathrm{kg} \text { bw/week })\end{array}$ \\
\hline $\mathrm{Cd}$ & 0.01 & 1.05 & 15 & $7^{\mathrm{b}}$ \\
$\mathrm{Hg}$ & 0.0002 & 0.015 & 0.375 & $4^{\mathrm{b}}$ \\
$\mathrm{Pb}$ & 0.01 & 1.2 & 4.8 & $25^{\mathrm{a}}$ \\
\hline
\end{tabular}

a Taken from [37]

$\mathrm{b}$ Taken from [38]

Zn. The contribution to DRV evaluation in the Slovak wine suggested a low dietary exposure for $\mathrm{Ca}, \mathrm{Cu}, \mathrm{Fe}, \mathrm{Mg}$, and $\mathrm{Zn}$ (Table 6). Also, the contribution to DRVs for elements like $\mathrm{Zn}$ and $\mathrm{Cu}$ indicates that consumed in excess, the Slovak wine does not pose a threat to human health.

Due to the $\mathrm{Cd}, \mathrm{Hg}$, and $\mathrm{Pb}$ trace amounts in organisms, the PTWIs for these metals were calculated. The PTWI is estimated by international scientific committee dealing with contaminants and additives in food. $\mathrm{Cd}, \mathrm{Hg}$, and $\mathrm{Pb}$ PTWIs are reported by the European Food Safety Agency [37]. The PTWIs of other metals studied are not currently officially regulated by law or norms [38]. We assessed the $\mathrm{Cd}, \mathrm{Hg}$, and $\mathrm{Pb}$ contribution to PTWI (Table 7) in the Slovak wine $(150 \mathrm{~mL} /$ one person/day). The estimated contribution to PTWI did not exceed the values proposed by the European Commission. Moreover, the contribution to PTWI evaluation in the Slovak wine suggested relatively low dietary exposure to heavy metals from the Slovak wine.

Based on the European Food Safety Agency report [37, 38] on the harmfulness of $\mathrm{Cd}$ in food, risk assessment based on the MOE value is recommended. MOE is the ratio between a defined point on the dose-response curve for the adverse effect and the estimated intake of food [39]. Systolic blood pressure (SBP) and chronic kidney disease (CKD) are treated as the most sensitive endpoints used in MOE approach. The European opinion concludes that MOE value of 10 or more brings no significant risk of clinical effects on SBP and change in the CKD. The risk of MOE greater than 1.0 is very low [37]. We assess the MOE for normal consumption (10 L/per capita/per year), high consumption (30 L/per capita/per year), and extreme consumption
(50 L/per capita/per year) of the Slovak wine [40]. Based on the MOE evaluation (calculated on the basis of mean metal concentrations), the consumption of Slovak wine poses no high risk of CKD and SBP (Table 8). Additionally, we noted that in the samples containing maximum concentrations of $\mathrm{Pb}$, the risk of CKD and SBP is high, especially for high and extreme consumption groups. Given the magnitude of the MOEs, the possibility of an effect on the kidneys and cardiovascular system in consumers with extreme daily consumption of Slovak wine cannot be excluded. For the maintenance of health, great deals of preventative measures should be taken to avoid consumption with food of potentially toxic metal ions.

\section{Conclusions}

It can be concluded that moderate consumption of Slovak wines may contribute to the daily dietary intake of essential elements and Slovak wines. The occurrence of $\mathrm{Cd}, \mathrm{Ca}, \mathrm{Cu}, \mathrm{Fe}$, $\mathrm{Pb}, \mathrm{Mg}, \mathrm{Hg}, \mathrm{Ni}$, and $\mathrm{Zn}$ in various types of wine produced in the Slovakia region was confirmed. The metal contents in the Slovak wines were most often similar to the concentration of metals in the non-Slovak wines. The type of wine and the alcohol content have no effect on the levels of metals in the Slovak wine. The age of wine has an impact only on the $\mathrm{Zn}$ concentration. The Slovak wines of more than 2 years of production have significantly higher concentrations of $\mathrm{Zn}$ than 2year or less-year-old ones, which can be affected by the production process and wine aging. We concluded that the estimated daily intake of one glass of Slovak wine containing

Table 8 Estimated MOEs for different endpoints by the intensity of Slovak wine consumption

\begin{tabular}{|c|c|c|c|c|}
\hline & $\mathrm{Pb}$ concentration $(\mu \mathrm{g} / \mathrm{L})$ & MOE_normal consumption & MOE_-high consumption & MOE_- extreme consumption \\
\hline \multicolumn{5}{|l|}{ Nephrotoxicity } \\
\hline & Wine $(\mathrm{Pb}$ mean 81.0$)$ & $0.5-1.6$ & $0.5-1.3$ & $0.4-1.2$ \\
\hline & Wine ( $\mathrm{Pb} \max .250 .0)$ & $0.5-1.3$ & $0.4-0.9$ & $0.3-0.7$ \\
\hline \multicolumn{5}{|l|}{ Cardiovascular effects } \\
\hline & Wine $(\mathrm{Pb}$ mean 81.0$)$ & $1.2-3.8$ & $1.1-3.2$ & $1.1-2.8$ \\
\hline & Wine ( $\mathrm{Pb} \max .250 .0)$ & $1.1-3.2$ & $0.9-2.1$ & $0.8-1.6$ \\
\hline
\end{tabular}

Margin of exposure (MOE) values calculated for normal consumption (10 L/per capita/per year), high consumption ( $30 \mathrm{~L} /$ per capita/per year), and extreme consumption (50 L/per capita/per year) [40] 
mean and maximum concentrations of $\mathrm{Ca}, \mathrm{Cu}, \mathrm{Fe}, \mathrm{Mg}$, and $\mathrm{Zn}$ provides less than $0.01 \%$ of TDI. Only EDI for Ni may be dangerous to human health. The contribution to DRV evaluation in the Slovak wine suggested a low dietary exposure for $\mathrm{Ca}, \mathrm{Cu}, \mathrm{Fe}, \mathrm{Mg}$, and $\mathrm{Zn}$. The PTWI evaluation in the Slovak wine suggested relatively low dietary exposure to heavy metals in the wine. MOE evaluation indicates that average consumption of Slovak wine poses no high cardiovascular and nephrotoxicity threat. However, the maximum concentration of $\mathrm{Pb}$ measured in the Slovak wines exceeds the maximum permitted level proposed by the European Commission. For those cases, the higher risk of CKD and SBP for high and extreme consumption groups is possible.

Acknowledgements This work was supported by projects VEGA 1/0857/14, 1/0760/15, 1/0039/16, APVV-0304-12, APVV-16-0289, and KEGA 006/SPU-4/2015. The research leading to these results has received funding from the European Community under project no. 26220220180: Building Research Centre "AgroBioTech."

Open Access This article is distributed under the terms of the Creative Commons Attribution 4.0 International License (http:// creativecommons.org/licenses/by/4.0/), which permits unrestricted use, distribution, and reproduction in any medium, provided you give appropriate credit to the original author(s) and the source, provide a link to the Creative Commons license, and indicate if changes were made.

\section{References}

1. SACR (2013) Slovak union of grape and wine producers. Slovakia a land of wine. Slovak Union of Grape and Wine Producers. Slovak Tourist Board, 1-36. Accessed: 18 May 2016 http://www.sacr.sk/ uploads/tx_publications/en_Wine.pdf

2. WHO (2014) Global status report on alcohol and health. World Health Organization, Geneva http://apps.who.int/iris/bitstream/ 10665/112736/1/9789240692763_eng.pdf

3. Gennaro MC, Mentasti E, Sarzanini C, Pesticcio A (1986) Undesirable and harmful metals in wines determination and removal. Food Chem 19(2):93-104. https://doi.org/10.1016/03088146(86)90103-2

4. Tariba B (2011) Metals in wine-impact on wine quality and health outcomes. Biol Trace Elem Res 144(1-3):143-156. https://doi.org/ 10.1007/s12011-011-9052-7

5. Hart EB, Steenbock H, Waddell J, Elvehjem CA (2002) Iron in nutrition. VII. Copper as a supplement to iron for hemoglobin building in the rat 1928. J Biol Chem 277:e22

6. Lieu PT, Heiskala M, Peterson PA, Yang Y (2001) The roles of iron in health and disease. Mol Asp Med 22:1-87

7. Maathuis FJ (2009) Physiological functions of mineral macronutrients. Curr Opin Plant Biol 12(3):250-258. https://doi.org/10.1016/ j.pbi.2009.04.003

8. Hänsch R, Mendel RR (2009) Physiological functions of mineral micronutrients (cu, Zn, Mn, Fe, Ni, Mo, B, cl). Curr Opin Plant Biol 12(3):259-266. https://doi.org/10.1016/j.pbi.2009.05.006

9. Das M, Das R (2012) Need of education and awareness towards zinc supplementation: a review. Int J Nutr Metab 4:45-50

10. Prashanth L, Kattapagari KK, Chitturi RT, Baddam VRR, Prasad LK (2015) A review on role of essential trace elements in health and disease. J NTR Univ Health Sci 4(2):75-85. https://doi.org/10. 4103/2277-8632.158577
11. Cabello-Pasini A, Macías-Carranza V, Siqueiros-Valencia A, Huerta-Díaz MA (2013) Concentrations of calcium, magnesium, potassium, and sodium in wines from Mexico. Am J Enol Vitic 64:280-284. https://doi.org/10.5344/ajev.2012.12080

12. Woldemariam DM, Chandravanshi BS (2011) Concentration levels of essential and non-essential elements in selected Ethiopian wines. Bull Chem Soc Ethiop 25(2):169-180. https://doi.org/10.4314/ bcse.v25i2.65852

13. Fleming J, Albus H, Neidhart B, Wegscheider W (1997) Glossary of analytical terms (VII). Accred Qual Assur 2:51-52

14. Chamannejadian A, Sayyad G, Moezzi A, Jahangiri A (2013) Evaluation of estimated daily intake (EDI) of cadmium and lead for rice (Oryza sativa L.) in calcareous soils. Iranian J Environ Health Sci Eng 10(1):28. https://doi.org/10.1186/1735-2746-10-28

15. EFSA (2015a) Scientific opinion on dietary reference values for calcium. Panel on Dietetic Products, Nutrition and Allergies (NDA). European Food Safety Authority (EFSA). https://doi.org/ 10.2903/j.efsa.2015.4101

16. EFSA (2015c) Scientific opinion on dietary reference values for iron. Panel on Dietetic Products, Nutrition and Allergies (NDA). European Food Safety Authority (EFSA), Parma. https://doi.org/ $10.2903 /$ j.efsa.2015.4254

17. EFSA (2014) Scientific opinion on dietary reference values for zinc. Panel on Dietetic Products, Nutrition and Allergies (NDA). European Food Safety Authority (EFSA). 12(10):3844 [76 pp.]. https://doi.org/10.2903/j.efsa.2014.3844

18. EFSA (2015b) Scientific opinion on dietary reference values for copper. Panel on Dietetic Products, Nutrition and Allergies (NDA). European Food Safety Authority (EFSA). 13(10):4253 [51 pp.]. https://doi.org/10.2903/j.efsa.2015.4253

19. EFSA (2015a) Scientific opinion on dietary reference values for magnesium. Panel on Dietetic Products, Nutrition and Allergies (NDA). European Food Safety Authority (EFSA), Parma. https:// doi.org/10.2903/j.efsa.2015.4186

20. Birch RM, Ciani M, Walker GM (2003) Magnesium, calcium and fermentative metabolism in wine yeasts. J Wine Res 14(1):3-15. https://doi.org/10.1080/0957126032000114973

21. Galani-Nikolakaki S, Kallithrakas-Kontos N, Katsanos AA (2002) Trace element analysis of Cretan wines and wine products. Chem Soc Ethiop 285:155-163. https://doi.org/10.1016/S0048-9697(01) 00912-3

22. Carvalho ML, Barreiros MA, Costa MM, Ramos MT, Marques MI (1996) Study of heavy metals in Madeira wine by total reflection XRF analysis. X-Ray Spectrom 25:29-32. https://doi.org/10.1002/ (SICI)1097-4539(199601)25:1<29::AID-XRS134>3.0.CO;2-Z

23. Angelovičová L, Fazekašová D (2014) Contamination of the soil and water environment by heavy metals in the former mining area of Rudňany (Slovakia). Soil \& Water Res 9(1):18-24 http://www. agriculturejournals.cz/publicFiles/111480.pdf

24. Pohl P (2007) What do metals tell us about wine? Trend Anal Chem 26(9):941-949. https://doi.org/10.1016/j.trac.2007.07.005

25. Teissedre PL, Vique CC, Cabanis MT, Cabanis JC (1998) Determination of nickel in French wines and grapes. Am J Enol Vitic 49:205-210

26. EFSA (2015) European food safety authority. Scientific opinion on the risks to public health related to the presence of nickel in food and drinking water. EFSA J 13(2):4002-4204

27. Wang R, Sun Q, Chang Q (2015) Soil types effect on grape and wine composition in Helan Mountain area of Ningxia. PLoS One 10(2):e0116690. https://doi.org/10.1371/journal.pone.0116690

28. Musilova J, Arvay J, Vollmannova A, Toth T, Tomas J (2016) Environmental contamination by heavy metals in region with previous mining activity. Bull Environ Contam Toxicol 97(4):569 575. https://doi.org/10.1007/s00128-016-1907-3

29. Vollmannova A, Kujovsky M, Stanovic R, Arvay J, Harangozo L (2016) Contamination of the alluvium of the Nitra River in Slovakia 
by cadmium, mercury and lead as a result of previous intense industrial activity. Bull Environ Contam Toxicol 97(4):561-568. https://doi.org/10.1007/s00128-016-1880

30. Kottferová J, Koréneková B (1995) The effect of emissions on heavy metals concentrations in cattle from the area of an industrial plant in Slovakia. Arch Environ Contam Toxicol 29(3):400-405

31. Ursínyová M, Hladíková V (2000) Chapter 3 cadmium in the environment of Central Europe. Trace Metals in the Environment 4: $87-107$

32. CR (2015) Commission regulation (EU) 2015/1005 on 25 June 2015, amending regulation (EC) no 1881/2006 as regards maximum levels of lead in certain foodstuffs. Off J Eur Union 58:9-14

33. Jaishankar M, Tseten T, Anbalagan N, Mathew BB, Beeregowda KN (2014) Toxicity, mechanism and health effects of some heavy metals. Interdiscip Toxicol 7(2):60-72. https://doi.org/10.2478/ intox-2014-0009

34. INMFNB (2001) Institute of Medicine, food and nutrition board. Dietary reference intakes for vitamin a, vitamin K, arsenic, boron, chromium, copper, iodine, iron, manganese, molybdenum, nickel, silicon, vanadium, and zinc. Standing committee on the scientific evaluation of dietary reference intakes. Food and nutrition board, Institute of Medicine. National Academy Press, Washington, DC, USA
35. FESNAD (2010) Federación Española de Sociedades de Nutrición, Alimentación, and Dietética. Dietary reference intakes (DRI) for the Spanish population. Actividad Dietética 14(4):196-197

36. Rubio C, Paz S, Ojeda I, Gutiérrez AJ, González-Weller D, Hardisson A, Revert C (2017) Dietary intake of metals from fresh cage-reared hens' eggs in Tenerife, Canary Islands. J Food Qual 111. https://doi.org/10.1155/2017/5972153

37. EFSA (2010) Scientific opinion on lead in food. European Food Safety Authority, Parma. EFSA J 8(4):1570. https://doi.org/10. 2903/j.efsa.2010.1570

38. JECFA (2011) Safety evaluation of certain food additive and contaminants. Prepared by the Seventy-third meeting of the Joint FAO/ WHO Expert Committee on Food Additives. Cadmium. Mercury. World Health Organization (WHO), Geneva, pp 305-684

39. Gašparík J, Binkowski ŁJ, Jahnátek A, Šmehýl P, Dobiaš M, Lukáč N, Błaszczyk M, Semla M, Massanyi P (2017) Levels of metals in kidney, liver, and muscle tissue and their influence on the fitness for the consumption of wild boar from western Slovakia. Biol Trace Elem Res 177(2):258-266

40. The Wine Institute (2015) World wine consumption. https://www. wineinstitute.org/resources/statistics. Accessed: 4 Oct 2017 